\title{
THE ESTABLISHMENT OF
}

\section{PUBLIC PARKS}

$$
\text { IN THF. }
$$

CITY OF NEW YORK.

\author{
BYY \\ GHERARIII DAVIS.
}

\author{
Read before
}

The New York Historical Society,

April 6, 1897 


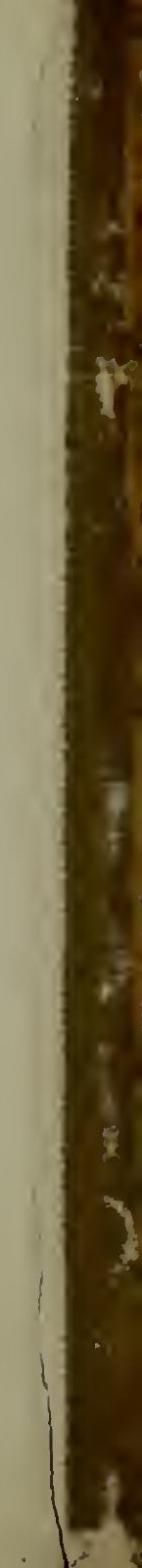




\title{
THE ESTABLISHMENT OF PUBLIC PARKS
}

\author{
win me \\ CITY OF NEW YORK. \\ BY
}

GHERARDI DAVIS.

Read before

The New York Historical Society, April 6, 1897.

$0 Y L 10374 \quad 80 \times 72$ 


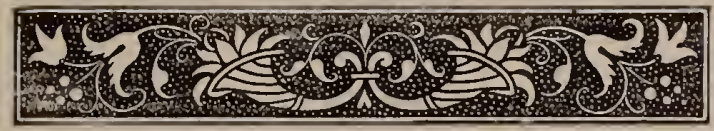

\section{THE ESTABLISHMENT OF PUBLIC PARKS IN THE CITY OF NEW YORK.}

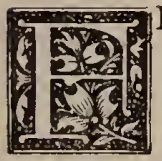

EW subjects have attracted more attention in matters relating to the comfort of the inhabitants of large cities than the question of Parks. Those stretches of green grass and trees have been well called breathing spaces for the people of a city; and as cities grow and become more and more densely populated, the need of parks is more and more recognized. The health of cities necessarily depends, to a great extent, upon these open spaces, where, especially in summer, people of all ages congregate in masses, to get at least a breath of open air, free from the heat and oppressing confinement of tenements. Our parks have not been always as jealously guarded as they should have been in the past, and in at least one instance in New York City a park was sacrificed to business needs. The memory of the beauty of this park is, perhaps, now tinged with sentiment, but no one can deny that such sacrifices are not only unnecessary, but are seri- 
ously to the disadvantage of the city and its inhabitants.

New York is a city of wonderful natural advantages, lying, as it does, between two broad rivers, where there is a heavy flow of tide, and this, probably as much as anything else, has made it healthy. But as New York becomes more and more built up, the demand for parks increases, and, within the last few years, vast tracks of land have been bought by the city for the purpose of laying out new parks.

With that pride which every one naturally has for the city in which he lives, we are inclined to think that our New York parks are the most beautiful in the world. We speak of Central Park as a wonderful production of landscape gardening, as, indeed, it is, and in a city so devoted to business as is New York, it is truly remarkable that so much space has been given up to mere trees and grass and water. But if we stop for a moment to consider the condition of things in this city, we quickly realize that New York is far from being the equal of some of our own cities, as regards trees and grass, and that many European cities are far better supplied with parks and avenues bordered with trees than is New York.

From the Battery to 59 th Street the area of the parks and squares is insignificant, and 
there is not one block of avenue with grass and trees like the Boulevard. And yet, in the very heart of London are the Gardens of the Inns of Court; near by are those of the Temple, from which the tree-bordered Embankment leads along the Thames to within a few rods of a series of parks, so that one can walk for miles from near the centre of this great city to its outskirts within parks and parkways.

Again, in Paris, not only are the various Boulevards lined with trees, but, from the site of the old Tuileries, in the very heart of Paris, to the gates of the city to the westward, there is a series of gardens, avenues and parks several miles long, which are famous the world over.

And even Buffalo, in this State, has been laid out with an eye to beaty as well as convenience. Delavare avenue, the pride of every inhabitant of Buffalo, with its fine trees, and the connecting avenues, squares and parks, lead from the business centre of the city to the Niagara River, a distance of about two miles.

Whatever may have been the causes which prevented the people of this City from preserving more open spaces south of 59th Street, the fact remains that in this part of the City, New York is far behind many American cities, as well as Paris, London and Vienna, and the citizens of New York must 
admit that their ancestors did not, in this respect, look to the future convenience and beauty of the City as they might well have done.

And yet the necessity of parks presented itself to some of the people of New York over a hundred years ago, for in 1785, August

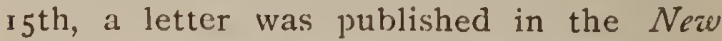
York Packet, addressed to the Mayor and Aldermen of this City, in which appeared the following:

"It is a very general complaint that there is not in this great City, nor in its environs any one proper spot where its numerous inhabitants can enjoy, with convenience, the exercise that is necessary for health and amusement."

The writer (whose name is unknown, he signs his letter "Veritas") goes on to speak of the faet that the well-to-do have ample means of getting fresh air by driving in summer and winter, an amusement whieh the greater part of the citizens cannot, of eourse, indulge in. He then refers to the well-kept parks of London and Paris, and the necessity of having parks in all cities, and he says, referring to the growth of New York:

"The size and consequence that this town must one day arrive at, ought strongly to impress the necessity of attending to this object, as well from a desire to contribute to the comfort and health of the inhabitants, as from the propriety of adding to the public orna- 
ments of the City. In this view the Battery naturally presents itself as a subject capable of vast improvement. Were the margin of this ground laid out with judgment, planted with a row of trees, and furnished with seats, from whence, after being jaded with the heats of August, we could enjoy the cool breezes of the evening, and admire the beauties of one of the finest harbors in the world-what an ornament would this city derive from it!"

How correct this writer's judgment was, all who have ever seen the Battery well know.

The Battery, however, was not the first open space in the City, which is now a park or square. It is the Bowling Green which has this distinction.

The name "Bowling Green" reminds us that in $\mathbf{1} 732$ certain gentlemen, Bowling who then lived in lower Broad-
Green. way, leased this plot of ground from the City, in order to play the now wellnigh forgotten game of bowls. As is well known, there once stood on the land south of the present Bowling Green Park a fort which dated back to the times of the Dutch. It was built in 1645 , and there Peter Stuyvesant and other noted men, including the Lieutenant-Governors of the Colony, resided. The entrance to this fort was on the side facing north, and in front of it was an open space, once called the Parade ( 1728$)$, kept open, as much as anything else, in order to 
prevent an attacking force from approaching too near the fort under cover. It was subsequently put to various uses by the citizens of the then diminutive city. In 1649 it was a cattle market; in 1676 a market fair was ordered to be held there, and later on it was used as a place of recreation. Its turf was apparently well cared for, as may be judged not only from the use it was put to as a bowling green, but also from the advcrtisement in 1745 for bids for laying new turf. In this year also the line of the houses on Broadway was ordered to be straightened, so as to improve the appearance of Bowling Green. The gallants and ladies of those days walked there, as they were afterward allowed to do on the ramparts of the old fort, little dreaming that in a few years this plot of grass would witness many acts that have become famous in the history of our eity.

In the middle of the square was erected in 1770 a statue of George III, made of lead, and standing on a pedestal, and in $177 \mathrm{r}$ an iron fence was put up around the green, which was then four-sided,not oval as at present. From pictures of the statue, it would seem to have resembled a hundred other statues of monarchs erected in Europe at about that time. After the Declaration of Independence a mob (at least such it was in the eyes of the English), tore down the 
statue and broke it in to pieces. The lead was used to make bullets by the Americans, but the base of the statue remained in the square for many years, until it was finally removed and its place taken by a fountain, in $\mathbf{r} 8 \mathbf{r} 8$. The slab which was on top of the pedestal is in the possession of the New York Historical Society.

In 786 Chancellor Livingston received authority to lay out Bowling Green as a green, and it has since then been one of the most pleasing of the smaller parks in this City. Its surroundings were much improved after the destruction and removal of the old fort. On the site of the fort the Government House was erected in I790. It was originally designed for the residence of President Washington, but, the Capitol being removed to Philadelphia, he never occupied it. It then became the Governor's house, and was the residence of Governors Clinton and Jay. The building was used for the Custom House from I 799 until r8I5, when it was taken down. It must have been a handsome building, old pictures of it showing it to have been of brick and stone, with a handsome portico of four columns the whole height of the building.

Bowling Green is too well known to require any very lengthy description or to be in need of any particular praise. It was at one time surrounded by fashionable residences, and 
for a time, in 1809 , the New York Historical Socicty occupied rooms overlooking it. Its trees and flowers still make it in summer a very attraetive spot, and even the overpowering height of the surrounding buildings eannot destroy its beauty.

No less beautiful is the adjoining Battery, in spite of the disfiguring mass Battery Park. of the elevated railroad struct. ure. It must be borne in mind that where the present Battery Park is, there was open water when the old fort, of which mention lias just been made, was built. This eondition of things existed until near the end of the XVIII eentury. Where the Staten Island ferry-houses now stand was open water. What is now Castle Garden was also under water. State Street was not laid out until I 789 , and then was bounded by the bay on one side. What is now Battery Place-in earlier days ealled Marketfield Street-was water. A ledge of rock stretched across the lower end of Manhattan Island (they are under the present park) and facing these rocks, along the edge of the water, there was built in the early days a line of works, then known as "The Battery." These works extended from Whitehall Street towards what is now Rector Street, and cannon were mounted behind them, which according to numerous accounts looked much more formidable than they actually were. The name 
which was then given to these works, "The Battery," will, it is to be hoped, always cling to this part of the city, and not be changed, as Chatham Street was changed, and as some people would have the Bowery changed.

In about 1723 the first steps were taken in connection with filling in in front of the fort, out towards the present water-line, but it took many years for the land to reach what is now the bulkhead line. During the Revolution the works along the water front were repaired and again armed, but as the Americans had no navy, and could not make an attack upon New York from the water side, they were never put to any practical use.

In 1806 the United States Government constructed Fort Clinton, now known as Castle Garden, upon land ceded to it by the State, some distance out into the water from the mainland, with which it was connected by a bridge. It was generally considered to be a formidable structure, but its use was not of long duration. In 1822, March 30, the United States Government ceded Fort Clinton to New York City, and in I823, June I6, it was entirely given up as a fortification. In May, I824, the City leased it as a place of amusement, and it became a fashionable resort known as Castle Garden. Upon the roof seats were built, sloping towards the interior. The building, it was said, could hold between ten and fifteen thousand people. 
All kinds of entertainments were had there, fireworks were let off, balloons were sent up, and glowing descriptions are to be found of the beauties of the place, where lanterns and colored lights and other decorations helped to make it attractive. There General Jackson was received, and General Lafayette was fêted. In 1847 the place became an opera house, in 1855 it was an emigration bureau, and in 1876 it was in part destroyed by fire. There Jennie Lind sang, and there hundreds of thousands of emigrants have landed. It is now an aquarium.

On the Battery Park itself, as early as I794, one Corre was licensed to sell small drinks. He occupied a kind of stand or kiosque, and this event was apparently of sufficient importance to be referred to in many books giving an account of the Battery at that time. Not far from his stand was a stone tower, surmounted by a flag staff, and called the "Churn," from the fancied resemblance of the structure to a churn.

As has already been said, the old fort which faced the Battery, as well as Bowling Green (its northwest bastion was at the corner of State Street and Bowling Green), was demolished in 1788 , and the space occupied by it and the gardens south of it were used for building purposes. Numerous private houses were built on its site, facing the water along State street, and many residences stood as 
well along Marketfield Street (now Battery Place), and along lower Broadway. There resided many of New York's old families, like the Rays, the Schermerhorns, the Primes, the Gracies, the Watts, but of their old residences few, if any, are now left. On State Street in particular, a few years ago, several old houses could still be seen.

In 1826 an iron railing was erected around the Battery. In 1844 the Battery is described as being one of the most beautiful places in New York City, although the writer says that it is abandoned to children. In fact, at that time both the Battery and Bowling Green seem to have been neglected by New Yorkers, who had already begun to make Sunday excursions up towards Harlem-a matter which brought forth bitter complaints in the newspapers by the Harlemites.

Beautiful as Battery Park is, and attractive as is the view which is to be had from it, there are few persons who would be willing to use the following romantic language, which is quoted from a description of this city made by a Philadelphian in 1806 :

"Were I an inhabitant of New York, I should like to pass the fine summer evenings there, particularly when the moon casts her mellow lustre on the surrounding waters, when the busy hum of men has subsided, and all is tranquil; when the slumbering winds just fan themselves into action, and bring refreshment to the fainting bosom." 
Leaving the Battery and going north along Broadwas past Trinity Churchyard and St. Paul's, one reaches City Hall Park, -ground which has witnessed many familiar incidents in New York history. One can hardly say of Broadway what a writer, a certain Mrs. Child, said in 1844 , on a walk to the park: "Why need I sigh for green fields? Does not Broadway superabound with beauty?" And yet, even to the matter-of-fact residents of New York, City Hall Park, especially in the spring, is still a very beautiful spot.

City Hall Park is but a small portion of

City Hall Park. what in the latter half of the seventeenth century was the Common Lands, a large arearof land stretching from where the Post Office now is, northward towards the Tombs, and from the present line of Broadway, east ward across what was at one time the Boston Post Road (now Park Row) to where the Sun Building and the entrance of the Bridge now stand. This land under the Dutch was used, as all Common Lands generally were, mainly for the grazing of cattle, and prior to 700 does not appear to have been the scene of anything historically interesting. It was in general a sort of undulating meadow, and at its nurtheasterly end was a pond, called the "Collect," or the "Fresh Water Pond," near where the Tombs now stand. One's imagination can 
run riot with the scenes of country life that must have been found here, and with tie views across the commons to the east, or Lispenard's Meadows to the north, but no imagination is needed to make this part of the city of historical interest to the citizens of New York.

The Commons were, as a portion of the unappropriated lands of Manhattan Island, granted by the Dongan charter, April 22, I686, to the Mayor, etc., of New York, and this grant was confirmed by the Montgomerie charter, February II, I730.

What ultimately became City Hall Park was very gradually carved out of the Com mons, the open space being steadily reduced in size by the laying out of streets, and by the construction of buildings. Thus near the site of the present City $\mathrm{Hall}$ was built a Powder House, in 1684, and in 1725 a gallows was erected near by. In 1747 a line of palisades was run across the Commons above where the present City Hall stands. It was about as useful as the old one at Wall street a hundred years or so before had been. In 757 what is now used as the Register's Office, (some times called the Hall of Records) was erected. It was built for a jail, and was known as the New Jail. In 1774 another building of equally sorrowful memories, the Bridewell, was built, west of what is now the City Hall, while 
north of it were erected barracks for the housing of the British soldiers. The site of the City Hall itself was at this time occupicd by an alms house.

As the City and its business grew, certain restrictions were naturally put upon the use of the Commons. Some werc very peculiar. Under a decree made in 1726 no hoop sticks were to be cut on the Commons; why, it does not appear. In I 734 an order was made that no fish should be caught in the Fresh Water Pond (which, as has been said, was situated near the present Tombs north of Chambers Street, on Centre Strect), except by angling. As business grew, the tanners established themselves at this end of the Commons, and werc allowed in $\mathbf{I} 745$ to tan at the Fresh Water Pond.

The boundaries of the Commons became more restricted when in 1760 Broadway was laid out. There had been a ropewalk along the Commons where Broadway now is. Chambers street was laid out about I760; Park Row is a part of the old Post Road. In ${ }_{7} 78$ the first steps were taken towards improving the present park, by making preparations for the sowing of grass. But in this space of twenty-seven years much had happened. The Revolution had occurred and the City had been the scene of much misery; the Colonies had gained their freedom and had become the United States, and 
New York had entered upon a new era. During these years City Hall Park was the scene of many exciting events which are well worth recalling:

In 1765 , the notorious Stamp Act aroused as much excitement in New York as it did in Boston. As soon as the stamps were brought to New York the good citizens held a meeting on the Commons to protest against this unjust infringement upon their rights and liberties. On November I of that year an excited crowd of citizens met there and proceeded in a body to Lieut.-Gov. Colden's stable under the guns of the fort at Bowling Green, carried off his coach to the Commons; erected a gallows with two arms, upon one of which the Lieutenant-Governor was hung in effigy, with a very forcible inscription attached, while from the other arm swung a figure of the devil. But not content with this, the mob paraded down Broadway again with the coach and the gallows, and, tearing up some of his Excellency's stockade, burned up coach and gallows and effigies under his very eyes.

His Excellency, the Lieutenant-Governor, thus describes this event in a letter to the Rt. Hon. H. S. Conway, November 5, I765:

“ In a day or two after the date of my Letter of the 26 th of last Month which I had the honour to write to you, the Packages of stamp'd Papers were landed from his Majesty's ship 
Garland at noonday without a Guard or the least appearance of discontent among the People. This gave me great hopes that I should be able to deliver up the administration of Government to Sir Henry Moore as 1 had inform'd you I had much at heart to do.

"But on the evening of the first day of this month the Mob began to collect together, \& after it became dark, they came up to the Fort Gate with a great number of boys carrying Torclies \& a scaffold on which two Immages were placed: Cne to represent the Governor in his grey hars, $\&$ the other the Devil by his side. The scaffold with the Immages was brought up within 8 or to feet of the Fort gate with the grossest ribalelry from the Mob. As they went from the Gate they broke open my coach house, took my chariot out of it, \& carried it round the Town with the Immages, \& return'd to the Fort Gate from whence they carried them to an open place, where they had erected a Jibbett within 100 yards of the Fort Gate, there hung up the Immages. After hanging some time they were cut down, \& burnt in a fire prepared for the purpose to. gether with my Chariot a single Horse chair and two sledges, our usual Carriage when Snow is on the Ground, which they took out of my Coach House. While this was doing, a great number of Gentlemen of the Town, if they can be called so, stood round to observe this outrage on their King's Governor. The Garrison was at the same time on the Ramparts with preparation sufficient to have destroyed them, but not a single return was made in words or otherwise from any Man in the Fort while this egregious Insult was performing. You may be assured, Sir, that the Peo- 
ple of this place have not had at any time the least provocation from me, either in words or any kind of action other than the receiving the Packages with the stamped Papers into the Fort, \& putting the Fort in a Posture of Defense, after open and bold Threats were made of takeing it by Force, tho' every artifice was used to make me say or do some rash thing."

Two days later (November 3, 1765 ), in order to prevent their use by the citizens, the guns along the Battery, of which there was a large number, were carefully spiked. It was surmised that this was done under Colden's instructions, and, as a matter of fact, the surmise was correct. When the citizens discovered this they took a cannon to the Commons, put on it the effigy of Lieut.-Gov. Colden, with a drill in his hands, as if he were working to get the spike out of the vent, and burned it amidst great excitement. But no open breach occurred between the citizens and the Lieutenant-Governor's forces, and with that singular change in opinion which sways a mass of people in a manner of ten quite unaccountable, when, in I 766 the Stamp Act was repealed, there was a great celebration by the citizens on the Commons in honor of the King's birthday. This was, however, one of the last acts done in honor of the King on that land by the Americans. For, with the erection of a liberty pole at the time of the celebration just spoken of, and its destruction in 1767 by the Eng- 
lish soldiers, began a series of tumultuous scenes, which culminated with the Revolution. The liberty pole was cut down four times, and each time re-erected on the Commons. The last one set up in 1770 stood until 1776 . In January, 1770 , there was a fight between the Sons of Liberty and the soldiers in front of the jail, arising out of a scurrilous article posted about the town by the soldiers after the destruction of the fourth pole. The fifth pole was raised in February in spite of opposition by the soldiers, and on land purchased by the Sons of Liberty somewhere near Warren street. It was strengthened and protected with iron bars and rods, and bore a vane, with the word "Liberty," and a flag, with the inscription, "Liberty and Property," the first of its kind in New York.

Event followed event rapidly until in July, 1776 , the Declaration of Independence was read on the Commons. Then came the battle of Long Island, which resulted in New York City being occupied by the English. The next years saw many American prisoners confined in the New Jail, with much suffering and no little unnecessary cruelty.

At the close of the war improvements in the Park began to be made. In 1792 the first post and rail fence were erected. In 1794 a lottery was authorized to raise funds for a new Alms House. The old Alms House was torn down and the new one erected in 1796 
on Chambers street. The erection of the present City Hall, the handsomest and best piece of architecture that has survived from those days was authorized in 1802 ; its cornerstone was laid by Mayor Livingston in 1803 , and in I 8 I I, July 4 , the Corporation met there for the first time. The building is well worth a careful examination, its handsome front and its interesting staircase, as well as its interior decorations, as far as they have escaped the blight of restorations, are as fine as anything of their kind in this country. It is built on three sides of marble, and the writer will surely be pardoned for referring to the fact that the north side was built of brownstone, and not of marble. This has recently been painted white.

In $182 \mathrm{I}$ an iron railing was put up about the Park, and at the entrance at the southern end there was a gate, the posts of which were surmounted by some old Turkish stone cannon balls, brought from the East by a Grecian pilot, as the story goes. It is said that this railing was brought into this country under a trick, so that the duty on it was much less than it should have been. But all this has long since disappeared, and on the site of this entrance stands now one of the greatest eyesores on lower Broadway, the Post Office.

The Alms House, which was built along what is now Chambers Street, and where, 
as has been said, the British barracks once stood, was occupied by the Historical Society and other institutions for a short period (about 1816). This building, afterwards known as the "New City Hall," was occupied in 1840 by the Marine Court and Court of Sessions; then it was used in part by the Law Library, while part of it was used for offices. In January, I $85^{6}$, it was destroyed by fire. On its site the new Court House was afterwards built.

In the mean time, the Park itself became more and more beautiful. When the Croton Aqueduct was built, a funtain was erected on the Broadway side of the park, which was spoken of with great enthusiasm. It was said that there was nothing equal to it in France or Italy. Its jets could be made to take various shapes, and when the water rose in a single jet it reached a height of 70 feet. Between 1800 and 186 I little of interest occurred in the Park. During the Rebellion sheds were built on the triangle, where the Post Office now stands, and there the soldiers were supplied with food. After the war, most unfortunately for the city, this plot of ground was transferred to the United States Government for its present purpose.

City Hall Park is unique in its character among New York parks. Through no other park in the city do such vast throngs of people pass every day. Every morning and 
every evening thousands upon thousands of men and women, young and old, cross between the City Hall and the Court House on their way to and from the Bridge. Judges, lawyers, clients, clerks and jurymen, and the numberless outside hangers-on of the courts, are to be seen about the Court House. Politicians are numerous about the City Hall, and the constant stream of wagons in Mail Street, is one of the many proofs of the size of the city and the extent of its business.

This park is the scene of the greatest excitement on election nights, and has at times been the scene of sorrowful processions and meetings, as when Lincoln's and Grant's bodies lay in state in City Hall. With all its past history it was quite fitting that the monument of Hale, who gave his life for the liberty of his country, should be placed so near to where the Sons of Liberty first erected their Liberty Pole, and fought to save this outward mark of their independence from destruction.

Still farther north in the City are to be found a number of well-known parks and squares, all of much more recent date, however, than the Battery and City Hall Park.

Madison Square was laid out as a Potter's Field in 1794 , at what was then

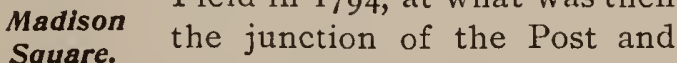
Bloomingdale roads, and was used by the Alms House as a burial place. 
Serious objections having been raiscd, howcver, by the property owners of adjoining land to its use for this purpose, it was abandoned in 1797 , and the Potter's Field was moved to Washington Square. In 1806 , the Unitcd Statcs Government erected in Madison Square an extensive arsenal which was subsequeutly abandoned. In 1823 the buildings for the Society for Juvenile Delinquents, one of the first institutions of its kind in the City, were erected on the square and there remained until 1830 , when they wcre destroyed by fire.

Washington Square, after being a parade Washington ground and a Potter's Field, be-
Square. me a public square, where resided for many years past. Here the Washington Arch has recently been erected, but the picturesque old university building is gone. The ceremonies attending the laying of the corner stone of the arch, and its final dedication, are too recent and too well known to be commented on. Like every other City Park, this squarc is crowded with mon, women and children in the summer, particularly in the evening, a striking pruof of the necessity of breathing spaces for the people of a great city.

On the plan of the Commissioners in 1807 , an enormous parade ground was laid out, extending from 23d Street to $34^{\text {th }}$ Street, 
and from Third Avenue to Seventh Avenue, Parade and including, of course, what
Ground. is now Madison Square, and
much other property. It is fortunate for the City that this parade ground was abandoned. Valuable as it would have been, it cottld not have been kept as a square, and would necessarily have been cut up by streets, for the reason that it blocked so many of the main arteries of the City. Imagine it crossed by two lines of elevated roads, three lines of cable cars, and numberless horse cars!

Union Square, which is situated at the

Union junction of the old Boston Post
Square. Road and the Bloomingdale
Road, now known as Fourth
Avenue and Broadway, respectively, is, from a historical point of view, no more important than Madison Square. In I 815 a small square called Union Place was laid out here, and appears to have been early enclosed in a railing, and ornamented with a fountain. It was not, however, until February $\mathbf{1}, \mathbf{1} 832$, that an act was passed enlarging the square to its present size. Until recently a stone was to be seen in the sidewalk upon the easterly side of Fourth Avenue opposite the square, bearing an inscription referring to its foundation.

Those who have not seen Union Square in summer can form no idea of its beauty and of the careful work done by the Department of Parks, in connection with the flowers 
and plants which are set out by it during the summer. Especially beautiful is the display of water plants in the fountain, where water lilies, lotus and papyrus, can be seen growing in great profusion.

Tompkins Square, situated on the east

Tompkins side of the City, between 7 th

Square. and roth Streets and Avenues $A$ and $B$, is a very large open space originally laid out in 1833 . It was used for a parade ground, and was at one time (about 1869), paved to a great extent. It has since been remodeled, and is now covered with grass. There, again, hundreds of people congregate during the evenings of the summer months.

Gramercy Park, which intersects Irving Place, between 20 th and $22 \mathrm{~d}$

Gramercy Streets, is the only remaining
Park. private park in New York. Gramercy Park, while it has not as fine trees as some of the other parks, is, nevertheless, well worth a visit, especially in the spring, as it is well cared for, and the trees and grass are always in grood condition. It was laid out by Mr. Ruggles, who owned much property around the park.

Some years ago St. John's Park, another

St. John's private park, once known as Park.

Hudson Park, the site of which is now occupied by the freight station of the New York Central Railroad, 
at Hudson and Laight Streets, was the pride of that part of the City, and there are undoubtedly some people who still think, with regret if not with bitterness, of the destruction of the park, and of its fine trees. These trees are referred to by many writers of New York, as it existed forty years or more ago, as being very beautiful.

Stuyvesant Square, through which Second

Stuyvesant Avenue runs, between isth Square. thus divided into two parts, is, as far as its western half is concerned, to be compared with any other of the small parks of the City. Like Gramercy Park, it is surrounded by a high iron railing, and it resembles that park, although it is not as picturesque.

The parks, the history of which has been followed so far, and of which some are among the oldest parks in the City, were not laid out pursuant to any particular plan or under any special law, and in some instances are but the result of a very gradual development. The parks at the Battery and the City Hall, and Washington, Tompkins, Union and Madison Squares, and the other open spaces in the lower part of the City, some of which have been public grounds for two centuries or more, were used either as squares, or parade grounds, or at times even for markets or burial places. They were 
maintained by the Board of Supervisors, the Commissioners of Streets and other city functionaries, who, from time to time were charged with that duty before the present Park Department was created. But Central Park and the other parks in the upper part of the City, were laid out upon well-clcfined lines and in pursuance of carefully conceived plans, and, in fact, the great development of the present park system, which now covers an area of more than 5,000 acres, was begun with the laying out of Central Park.

In 185 I Mayor Kingsland addressed the Common Council in a short, Central spirited message on the subject of new parks in New York. He urged the Committee on Lands and Places to examine into this question, and the matter was taken up so promptly and vigorously that in July, $185 \mathrm{r}$, at a special session of the Legislature, an act was passed authorizing the taking of St. John's Wood as a park. This was a wild and beautifully wooded tract of land lying between 66 th and 75th Streets, Third Avenue and the East River, with a high, steep bluff overlooking the river.

Hardly had this act been passed when vigorous opposition was aroused, prompted mainly by worthy motives, in part, it is said, by personal feeling, and a very strong movement was begun in favor of what is now 
Central Park. A committee of the Common Council reported strongly in favor of Central Park, and in July, I853, an act was passed creating a Commission, and authorizing the taking of land between 59th Street and ro6th Street, Fifth Avenue and Eighth Avenue as a public park. The proceedings which were subsequently commenced for acquiring title to the land, were confirmed February 5, 1856, and on the I 7 th of April of the following year an act was passed designating the land as "The Central Park," and providing for its laying out, improvement, regulation and government by a board consisting of eleven persons, styled "The Commissioners of the Central Park." This commission consisted of Robert J. Dillon, James E. Cooley, Charles H. Russell, John F. Butterworth, John E. C. Gray, Waldo Hutchins, Thomas C. Fields, Andrew H. Green, Charles W. Elliott, William K. Strong and James Hogg. By an act passed April 2, I859, the lands for the Park were extended northerly to I roth Street.

The Commissioners entered upon their duties early in the year 1859 , and vacancies, which until A pril, 1859 , were filled by nomination of the Board, added to the Board August Belmont, Henry G. Stebbins, Richard M. Blatchford and Moses H. Grinnell. In the spring of 1870 the charter of that year created the Department of Public Parks, to 
be governed by a board of five members, and extended the jurisdiction of the Department over all parks and public grounds above Canal street. A law of a few days later, amending the charter, included the remaining parks south of that street. This law remained in force until 1873 , when the present charter reduced the Board to four members, its present rumber.

The Commission appointed in 1853 called for plans for the Central Park, and thirtythree were submitted-some fantastic, some wholly unpractical, others good. But the design which seems to have been unquestionably superior to all others, and which all see and enjoy in its execution, was that submitted by two men, whose names will ever be associated with this wonderful piece of work-Frederick Law Olmsted and Calvert Vaux.

While it would not be possible to describe the Olmsted and Vaux plan, it may be well to refer to some of the methods pursued in laying out Central Park. There was to be a driveway so laid out as to give as long and as beautiful a road as possible. There were to be cross-drives and walks for pedestrians; there were to be ponds and cascades, meadows and flower beds; there were to be gates at various points, and they appcar on the maps with such name as Scholars' Gate, Artists' Gate, Strangers' Gate, Woodman's Gate, 
Warriors' Gate-names which are seldom, if ever, applied. Great care was taken to preserve as much as possible of the natural beauty of the ground. At the same time, in many instances, the skill of the landscape gardener was applied to the production of effects so like Nature that it is difficult to tell where Nature ends and landscape gardening begins.

The grounds now forming Central Park were described forty years ago as being thickets and swamps, pestilential pools and rocky gulleys, covered with unsightly hovels, and their attending nuisances. The character of the soil was rough, covered with rank herbage, and without much healthy vegetation. All this has been changed. While the general topography remains the same, and the lakes and water-courses are natural, they were subjected to careful treatment to secure the best effects. Thus the westerly end of Harlem Creek, which extended from I Ioth Street and Fifth Avenue to the East River, was made into a lake; the ravines just west of this lake were carefully preserved, and the wisdom of the extension of the park from ro6th to I roth Streets is apparent to all who know this part of Central Park.

From old Fort Fish, at the northeasterly end of the Park, on one of its highest points, one can easily follow with the eye the chain of hills which extends across Man- 
hattan Island from about $125^{\text {th }}$ Street and North River in the direction of 8oth Street and East River. These hills run south from $125^{\text {th }}$ Street, forming a ridge on which now stand Columbia College and St. Luke's Hospital, and upon which the Cathedral is to be built. Their eastern face is now known as Morningside Park; their western slope is Riverside Drive. At I loth Street a line of hills branches off east and south across the northern end of the Park, and thence to the East River. These hills were crossed by McGowan's Pass, and along the top of the hills were constructed various military works during the Revolution, and again at the time of the War of 1812 . The remains of some of the old fortifications erected in 18,2 can still be traced, among others, Fort Fish. It defended McGowan's Pass, which crossed the hills near what is now the East Drive. A great many remains of military works have been discovered in this neighborhood, in making excavations for improvements, and on the elevation known as Great Hill, on the westerly side of the Park from 104th to 106 th Streets, traces of old encampments were found in the shape of tent floors, camputensils, and other similar articles. The Block House, at the northwesterly corner of the Park, overlooks the hills over which the British retreated in the Battle of Harlem Heights. As has been more than once described in 
papers read before the New York Historical Society, they passed over the present site of Columbia College, and crossed to where the northwest corner of Central Park now is, followed by the Americans to near this point.

From the hills at the northern end of the Park to the great Reservoir, the land is very irregular, and here and there the rocks show unquestioned traces of the action of ice. Just north of the Reservoir in a broad valley are the meadows, where in summer tennis courts are laid out, and hundreds of people enjoy themselves at this game. Standing here, it is difficult to believe that one is in a city, less than half a mile away from elevated roads and cable cars, and all the other roar and bustle of a very noisy city.

The southern half of Central Park differs very much from the northern part. It has been laid out more artificially than the upper end, and has been much more carefully cultivated and ornamented. This was of necessity the case by reason of the different formation of the land, there being no such natural beauties in this part of the park as are to be found among the hills and rocks at the northern end. Nevertheless, the fine trees along the Mall and elsewhere, the broad meadows and the lakes, well merit admiration, and anyone who has been in Central Park about the first of 
May will be convineed that these meadows are without question the rreatest playgrounds of the ehildren of New York. Near, too, we find the Metropolitan Museum of Art, whose influenee has not, however, prevented the eontinued existenee of such statues as those of Burns and Scott.

Of eourse, the eost of the land taken for Central Park was great, the amount being over five millions, and its eonstruetion and maintenanec, as the writer is informed by the Seeretary of the Park Department, has cost up to the present time upwards of fifteen millions of dollars. The area of Central Purk is 840 acres, its length a little more than $2 \frac{1}{2}$ miles, and its width a trifle over $\frac{1}{2}$ a mile. The space oceupied by the Croton Water Reservoirs and the Transverse Roads reduees the aetual park area to about 683 aeres. Its lakes and ornamental waters cover an area of nearly $44 \frac{1}{2}$ acres. What the value of the land is, it is diffieult to say. Ex-Mayor Gilroy put it, in an article written by him on the wealth of New York, at two hundred millions, and it ean hardly be doubted that this is a reasonable estimate of its value. The great improvements made in the Park have at the same time unquestionably affeeted adjoining property, and helped to enhanee its value. In 1856 , the year before the Park was taken, the assessed value of land and property in the various 
wards adjoining Central Park was somewhat under twenty-one millions, while in the year i 895 its value had risen to over six hundred and eighty millions. Much of this increase is without doubt due to Central Park.

After Central Park was laid out, nothing was done for some years in connection with adding additional area to the park lands of the City, but in 1869 what is now known as Riverside Park was laid out along the westerly slope of the hills, which Riverside have previously been spoken of
Park. as running south from $125^{\text {th }}$ Street. The bank of the North River is here high and steep, and no better use could have been made of it than that to which it has been put. The land for the park was acquired in 1872 at a cost of over $\$ 6,000,000$. The area of the park is 177.8 acres. The first improvement was the construction of Riverside Drive, from $72 \mathrm{~d}$ Street, north, which was opened to the public in $\mathrm{I} 880$, and is now practically complete, with the exception of a viaduct, which is to carry it over the depression at $9^{6 \text { th }}$ Street. The park on the west of the Drive, that is, on the slope of the hills running down to the river, has not yet been completed, but much work has been done in planting shrubs and in the preservation of trees, many of which are fine and large, and the result of natural growth. At 
the upper end of Riverside Drive is the well. known Claremont, overlooking the river, and here is the magnificent tomb of General Grant. Near by, in striking eontrast, is the odd little monument erected to the memory of "An Amiable Child," around which many sentimental stories have been woven.

Morningside Park runs along the easterly slope of the range of hills, the westerly slope of which is taken up by Morningside
Park. side and Central Parks do not quite meet, but are so connected by broad streets, that one may drive or walk from $72 d$ Street and the North River up to 120 th Street across to Morningside Park, and south again to Iroth Street, thenee to Central Park, and through that park to 59 th Street, nearly all the way within the domain of eity parks. Those who ride a bieycle are undoubtedly familiar with this streteh of park land. Morningside was a few years ago a rugged bluff of bare roeks, now made beautiful by shrubs, grass plots and flowers, where under the usual New York system of laying out streets, one might have expected to find gullies with vertieal walls of rock, like railroad cuts.

Much money had to be spent in aecomplishing the results obtained here, and Morningside Park, which contains slightly over 3 I acres, has cost over $\$ 1,500,000$ for the land 
alone. But the results are well worth the money spent. At the northerly end of the Park are further remains of some old fortifications of $18 \times 2$.

The view east from the top of this park is well worth seeing. The roadway overlooks the flat land of Harlem, and beyond this one sees the East River, and far beyond Long Island and the upper end of New York across the Harlem River.

The stretch of parks from 59th Street and Fifth Avenue to $125^{\text {th }}$ Street and the North River is unrivalled for beauty in any city in the world. Much admiration seems to have been wasted on the plan adopted by the Commissioners in 1807 , in so far as it made provision for parks. Too much, however, cannot be said in praise of Mayor Kingsland and the able Commissioners who had charge of Central Park, and adopted the Olmstead and Vaux plans. Nor can too much be said in praise of the policy which led to the creation of Morningside and Riverside parks, and has since led to the laying out of parks north of the Harlem.

In the early eiglities a new burst of energy Parks North of led to the extension of the City's the Harlem. park domain in a wholly unprecedented manner. Instead of waiting for New York to cover what is known as the Annexed District, and then procreding to lay out parks, the City has wisely 
adopted a very extensive plan for new parks, bought the land and begun to improve it, tlus anticipating the needs of an ever-increasing population north of the Harlem. This was done under an act of the Legislature of April 19, 1883, which provided for the appointment of Commissioners to select and locate lands for public parks in the 'Twentythird and Twent $y^{\circ}$-fourth wards and in their vicinity. Under this act Mayor Edson appointed Luther R. Marsh, Louis Fi:zgerald, Waldo Hutchins, Charles L. Tiffany, William W. Niles, George W. McLean and Thomas J. Crombie, and, following their report to the Legislature, that bocly passed a law on June 14, 1884, laying out and providing for the acquisition of the following parks :

Van Cortlandt, which contains. I, 132.35 acres.

Bronx, which contains...... 661.60 "

Pelham Bay, which contains... $1,75^{6}$

Crotona, which contains...... 141.65

Claremont, which contains ... 38.05

St. Mary's, which contains.... 28.70 “

Bronx and Pelham Parkway,

which contains......... 95

Mosholu Parkway, which con-

tains................ 80

80 "

Crotona Parkway, which con-

tains .............. I2

a total of .......3,945.35 acres, that is, an area nearly five times that of Cen- 
tral Park. At that time the total area of the city parks was only r,094 acres-less than Van Cortlandt Park alone.

The report of the Commission appointed to acquire the lands was confirmed by the courts in the year 1889 . The total cost to the City of acquiring the land was $\$ 9,969$,603.04. These parks reach from the Sound nearly to the Hudson, and cover a vast area of beautiful country, where there are hills and valleys, meadows and woods, streams and lakes, far surpassing in beauty Central Park.

The development of these new parks will be gradual with the growth of the city, and consistent with economical expenditure. For, of course, it was not intended that these vast park lands should be immediately completed. Their area is so great that the expense would be prohibitory. Comparatively little has been done as yet toward the permanent improvement of these parks, with the exception of the parade ground in

\section{Van Cortlandt} Van Cortlandt Park, where a and

Bronx Parks. proved and set apart for the use of the National Guard. Some work has also been done in connection with the macadamizing of a part of the roads in Van Cortlandt and Pelham Bay Parks. A new roadway is now being constructed on the line of the Bronx and Pelham Parkway, 
and this, and other similar work, is being carried on by the Department with an expenditure of several hundred thousands of dollars annually. Each year's work may not show for itself, but the result will, in a few years, be very apparent.

The natural beauties and peculiar fitness for a public park of the lands lying along both banks of the Bronx River led to the selection of this valley by the Park Commission for what is now Bronx Park. As that Commission said in its report to the Legislature: "That such a spot should exist in its original state, in its native wildness, so near the scttled portion of the great city, and yet be almost so wholly unknown and unsuspected, will awaken surprise," The river runs through the park from end to end, over rocks and old mill dams, and here and there forming small ponds. Along its banks is a rich growth of trees and shrubs, as wild in appearance in places as if the hand of man had never touched them. Among them is a fine tree of over 150 feet in height, which has long been know1l as De Lancey's pine, having received its name, it is said, from the De Lancey family, who formerly owned the land. There is also a huge boulder, which is evidently a glacial deposit, weighing probably more than 100 tons, yet so balanced on the rock upon which it was 
originally deposited ages ago, that it can easily be made to swing on its rocky base. The reservation set apart for the use of the New York Botanical Garden and Arboretum in Bronx Park covers an area of $25^{\circ}$ acres of land. The Park Board has also approved of the use of a portion of the same park for the purposes of the New York Zoological Society-a decided improvement on the present Zoological Garden in Central Park.

St. Mary's Park, Claremont Park and Crotona Park, all south and west of Bronx Park, do not call for any particular mention. There is, however, a feature of the new park system which ought not to be overlooked, and that is the Parkivays,-broad avenues connecting Bronx Parks with

Parkways. Van Cortlandt, Pelham and Crotona Parks. They are several hundred feet wide, and are so laid out that one can pass from one park to another, without going through city streets-a plan which ought to have been adopted to connect Central Park with Morningside and Riverside. These parkways are Mosholu Parkway, connecting Van Cortlandt with Bronx Park; Crotona Parkway, connecting Crotona with Bronx Park, and the Bronx and Pelham Parkway, which connects Bronx Park with Pelham Bay Park on the Sound. 
Pelham Bay Park has onc feature which

Pelham Bay no other park possesses, and Park.

that is its water front on the Sound, just back of Throggs

Neck. The laying out of this park was in part urged in order that the people might have aceess to the water by way of a park. No one who has seen the Sound on a summer afternoon can doubt the wisclom of the Commission which laid out this park so that it should reach the water. Objection was made that it was outside, of the city, and it is true that the park was originally in Westchester County. But no equally well-situated land was to be had nearer to the city, and when the so-called Annexed Distriet beeame part of New York, this park was brought within the city limits, its northerly boundary being the same as the northerly boundary line of the city at this point.

This Park, too, is of historical interest. Here vecurred on Octobcr 18, 1778, a fight between the British and the Americans, when General Howe made an effort to get in the rear of Washington's army, and cut it off from its base of supplies in Connecticut, just before the battle of White Plains. There, too, the Hutchinson River recalls the romance of Anne Hutchinson.

The incidents connected with the land where these parks are situated, and relating to our early history, have often been told in 
the New York Historical Society in a manner far more complete and more interesting than the writer can possibly relate them. There is the Old Manor House in Van Cortlandt Park, a residence of the Van Cortlandt family, erected in the middle of the XVIII century ( $\mathrm{I}_{748} 8$ ), where General Washington and Rochambeau dined just prior to the Yorktown campaign. When Washington decided in July of 1781 to join Lafaye tte at Yorktown, he lighted his camp fires on the summit of Vault Hill to deceive the enemy in regard to his movements. The vault, which gives its name to this spot, was the burial place of the Van Cortlandt family, and still exists. The country near this and the Mosholu Valley was the scene of many bloody fights between the Stockbridge Indians and the English. The spot, known as Indian Field, received its name from a grave, which is said to have held the remains of forty Indians.

There are still a few smaller parks to be mentioned, several of which SmallerParks have been recently laid out,
and Squares. and all of which were designed and constructed, like Central Park, solely for the purpose of creating open spaces for the benefit of the public.

Manhattan Park, which surrounds the Natural History Museum, does not call for any especial comment. With the completion of the Museum, there will be hardly any of 
the open space left, and, as a park, it will practically disappear.

Bryant Park, between 40 th and 42 d streets, known to most people because of its proximity to the old reservoir, is as beautiful a spot as can be found in the city. It is here that the new Public Library is to be erected.

Mount Morris Park, which lies across Fifth avenue at $124^{\text {th }}$ street, is well worth more than a mere passing notice. It is a large space in the centre of which is a bold, rocky eminence formerly called Snake Hill, or, in Dutch, Slange Berg. After having remained an abandoned space for many years, the records show that in 1869 work upon it was being actively pushed, and it was soon com. pleted as a park. The fact that it contains a hill, which rises abruptly above the sur. rounding streets, adds very much to its beauty.

East River Park, which lies at the foot of 88th street and the East River, is one of the most recent of the public squares or parks which has been opened. It is near, or covers a part of the old country places of a number of well-known New York families, like the Gracies, Schermerhorns, Crugers, Waldrons and Rhinelanders. The house which stands at the point overlooking the water was formerly the residence of Mr. Gracie, one of the ancestors of a well-known family of this city. It overlooks the waters of $\mathrm{Hell}$ Gate with 
Mill Rock and the upper end of Blackwell's Island but a short distance away. Many of the trees on this country place, until recently, overhung the water. The writer has heard one of Mr. Gracie's descendants say that in the early part of the century a large warship, passing throngh $\mathrm{Hell}$ Gate, was carried by the current so near the bank that her yards caught in the trees, while the ship floated in deep water.

For the past few years greater attention has been directed toward the acquisition and improvement of additional parks in the lower portion of the City, and more especially in the crowded tenement honse districts. Corlear's Hook Park, in the Seventh Ward, is very near the site of a garden, where a hundred years since New Yorkers were accustomed to go for refreshments and amusement. It and Mulberry Bend Park, in the Sixth Ward, now take the place of squalid tenements. Jeanette Park, at Coenties Slip, is a small plot of green along the water's edge, and Old St. John's Cemetery lands, in the Ninth Ward, have just been acquired for park purposes, and are about to be improved. Other proceedings are now pending for acquiring title to parks in the lower part of the City as a result of the efforts of the Tenement House Commission to procure breathing spaces, where most needed, for the relief of the poorer classes. The acquisition of 
Fort Washington Park a few months ago, and the proposed Colonial and St. Nicholas Parks, on the upper West Side on Manhattan Island, will still further increase the park area of the City and add much to its beauty.

To go further into this interesting subject would lead to the presentation of a mass of figures and scientific descriptions, if an attempt were made to examine the laying out of the parks from the point of view of the landscape gardener; or the dry domain of legal technicalities, would soon be reached if the writer were to go farther into the question of how the land was acquired for the parks; or again, it would call for a review of much of the history of the City, if reference were made at any greater length to the historical events connected with the parks and the land they occupy. To do justice to the beauties of the landscapes in the City parks, calls for an artist rather than a writer.

New York may well be proud of the work done by the Park Departinent during the past twenty years, for the care which the Commissioners of that Department have bestowed upon our park system has already to a great extent made up for the former lack of parks in the lower half of the city.

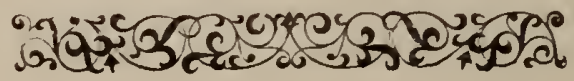




\section{NOTE.}

In the libraries of the New York Historical Society and of the Association of the Bar there are many interesting maps showing, among other things, the development of Battery Park.

The former library owns a unique set of water-colors, made in 1812 , of the defenses of upper New York, which show quite clearly the appearance of Manhattan Island in the neighborhood of the present I Ioth Street from river to river.

The Manuals of the Corporation contain not only much information about the parks, but also many views of Central Park, the Battery, etc.

The reports of the various Commissions should be consulted for information about the original laying out of the new parks.

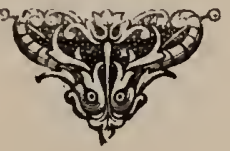



